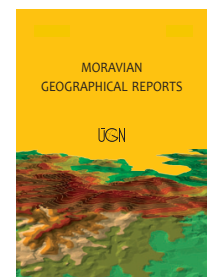

MORAVIAN GEOGRAPHICAL REPORTS

\title{
Characterising the flows of Slovenian tourists within the former Yugoslavia with respect to post-communist 'nostalgic context'
}

\author{
Metod ŠULIGOJ a *
}

\begin{abstract}
Slovenia represents a key source in the tourist market for the new post-Yugoslavian states, but little is known about Slovenians' tourism practices, especially in relation to the post-communist dimension. The term "Yugonostalgia" came into existence in the 1990s in the post-Yugoslav area, and it illustrates the attitudes of people looking for a life that would be better than their present one. The term is also connected to tourism, although it has been largely neglected in the tourism literature. In this study, a total of 384 appropriately completed questionnaires were recorded and prepared for empirical analyses. Some 83.0\% of respondents repeatedly return to a former Yugoslav destination they had visited in the past. Hierarchical and nonhierarchical clustering methods were used to identify clusters. Subsequently, cross-tabulations were employed to profile each cluster based on demographic characteristics, and chi-square tests were performed to validate the clusters and their mutual differences. Significant differences between groups with respect to survey variables were verified by one-way analysis of variance models. Three significantly different clusters were identified: (i) friends of nature; (ii) immigrants and their descendants (from the post-Yugoslav states); and (iii) moderate lovers of nature and culture. None of identified clusters are characterised by Yugonostalgia: group members behave in similar ways to all contemporary tourists with varying individual interests, which is an additional interesting finding.
\end{abstract}

Keywords: Yugonostalgia, post-communism, thematic tourism, former Yugoslavia, Slovenia

Article history: Received 12 May 2017; Accepted 10 February 2018; Published 31 March 2018

\section{Introduction}

The tourism industry of the $21^{\text {st }}$ century is increasingly establishing itself as an "experience industry" in which tourists are looking for emotional stimuli; they want to buy feelings (personal experiences) instead of products the immaterial qualities, seeking ambiance, aesthetics and atmosphere, looking for an experience full of varying intimacies, intensities and complexities (Opaschowski, 2001). Tourism experiences are multi-phasic and evolve over time (Stewart, 1998). The tourism experience, consisting of anticipation, consumption and memory phases, is interpreted "within the broader, narrative context of the consumer's life" (Arnould and Price, 1993).

Linking tourism with memory is not a new approach (see Tung and Ritchie, 2011), but it is important because there is a "global epidemic of nostalgia, an affective yearning for a community with a collective memory, a longing for continuity in a fragmented world" (Boym, 2007). Nostalgia can influence a person's behavioural intentions (Chen, Yeh and Huan, 2014), when an individual's desire for authentic (cultural) experiences to escape their everyday environment is triggered (Osbaldiston, 2012). In this sense, the nostalgiadriven traveller is pushed by his/her innate motives to travel and pulled by several destination-specific attributes (Leong, Yeh, Hsiao and Huan, 2015; Ryan, Shuo and Huan, 2010; Yoon and Uysal, 2005).

Although Slovenian tourists represent a key source market for the new post-Yugoslav states (The Socialist Federal Republic of Yugoslavia or SFRY - see Fig. 1) little is known about their travel-related behaviours, especially in relation to the nostalgic dimension. Only the research by Šegota and Jančič (2012, 2013), which is focused on the so-called Yugonostalgia as a motivator for visiting Croatia by Slovenians, and the research by Velikonja and

\footnotetext{
${ }^{a}$ Faculty of tourism studies - Turistica, University of Primorska, Portorose, Slovenia (*corresponding author: M. Šuligoj, e-mail:metod.suligoj@fts.upr.si)
} 
Majsova (2014) on the tourist aspect of the creation of this ambiguous, imaginary SFRY, have a tourist connotation, while many others do not (e.g. Bancroft, 2009; Boym, 2007; Kuzmanić, 2008; Velikonja, 2008). Researching nostalgia or Yugonostalgia is especially important because much can be learned about the present - people remember pleasant times when they belonged to an entirely different country (Bancroft, 2009, pp. 5-6; Palmberger, 2008); as well, they remember and recognise unrealised opportunities that can affect the present (Bošković, 2013, p. 77).

Consequently, the aim of this paper is not 'historical revisionism' nor 'regime promotion', but to explore attitudes toward the recent past in Slovenia (as one of the successor states of the socialist federation) and the current travelrelated views of its residents. Their mental, virtual and real journeys in the area of the former SFRY can be symbolically described with the song "From the Vardar River to Mount Triglav", officially called "Yugoslavia" (Jugoslavijo in Serbian), which describes many dimensions of the former SFRY, such as natural beauties, liberation struggles and the labour of the SFRY's working people, and was alive in the time of the last economic crisis. This song by Serbian Milutin Popović Zahar, author of many Yugoslav "Greatest Musical Hits", was performed by the Croatian female vocal ensemble Ladarice, which became famous immediately after Tito's death (1980). It could be argued that this song reflects a journey from one area to another of (the former) SFRY, and thus describes Slovenian tourists. The question here is, following the example of Rekść (2015, p. 110), who in the former USSR case labelled nostalgic people as Homo Sovieticus, in the former SFRY area - "can we label Yugonostalgic people as Homo Iugoslovanicus?". This question is also relevant in terms of tourism geography exploring motives and the needs of travellers are important for some tourism geographers, such as Jeršič, 1985, and Rančić, Blešić, Đorđević and Bole, 2016. Geographers have also focused on specific interest tourism, e.g. religious tourism (Collins-Kreiner, 2010), wellness tourism (Rančić, Blešić, Đorđević and Bole, 2016), dark tourism (Mansfeld and Korman, 2015) and similar specialties.
An affective memory about a system and nostalgia about it usually emerge as a consequence of every transformation appearing to leave some social group(s) outside the change (Boym, 2001, p. XVI). In fact, this has happened in the former SFRY republics, where members of the former working class, which was the key pillar of society under socialism, now often feel humiliated. At the macro level, however, Slovenia today delivers much better economic results than before 1991 and better than the other countries that emerged from the former SFRY: see Biloslavo and Kljajić-Dervić (2016); Šuligoj and Štrukelj (2017). In addition, this social and economic situation triggers many paradoxical travel habits of Slovenians, the nation which was the first to leave the SFRY and the first to be attacked by the Yugoslav Army in June 1991. Slovenians have some distinctive tourist patterns:

i. enormous levels of summer vacationing on the Croatian coast;

ii. massive New Year's Eve celebrations in Belgrade (Serbia);

iii. among the main visitors to Kumrovec (Tito's birthplace in Croatia) or Jajce (the "birthplace" of post-World War II Yugoslavia in Bosnia: see also Kurtović (2011));

iv. travel for medical reasons or for cheap shopping [in the Republic of Srpska an entity of Bosnia and Herzegovina)]; and

v. 'not to mention' countless business trips as part of the socalled MICE tourism (Meetings, Incentives, Conferences and Exhibitions/Events).

Are Slovenian tourists Yugonostalgic when they decide to travel to the former SFRY destinations, which are today (simultaneously) marked with post-communist/post-socialist transitions, post-conflict recovery and (presently) highly complex inter-ethnic relations and incompatibility? What kinds of tourism products are they looking for? These are all questions that other contemporary studies do not include, although they are important for the academic world (e.g. for sociologists, economists, anthropologists, geographers),

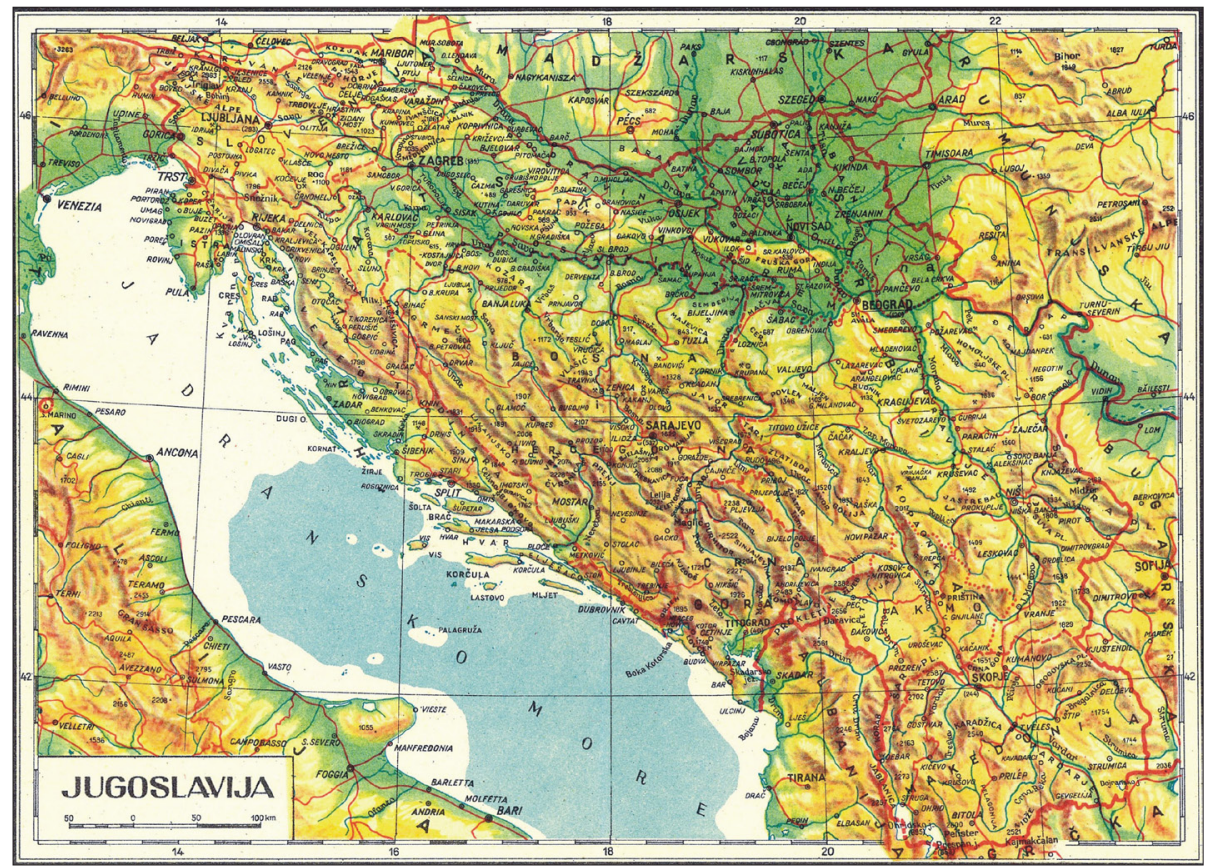

Fig. 1: Map of former Yugoslavia (SFRY)

Source: Novak (1968) 
as much as for the tourism industry (e.g. tour operators/ agencies, tour guides, experts in tourism marketing, developers of tourism strategies, etc.) - in the wider "postsocialist region".

\section{Nostalgia and Yugonostalgia}

The pseudo-Greek word nostalgia was coined by the Swiss student Johannes Hofer in his medical dissertation in 1688, which clearly demonstrates its medical, not social origins (Bancroft, 2009, p. 10; Boym, 2007, p. 7; Holak, Havlena and Matveev, 2005, p. 195; Palmberger, 2008, p. 358). There are many definitions of the term: "commonly understood as a hazy perception of the past that glorifies what was and is no more, while downplaying all the shortcomings of the past" (Palmberger, 2008, p. 358; Rekść, 2015, p. 106; Smeekes, 2015). The beginnings of the development of the concept in a broader sense is explained in Starobinski (2009) and Boym (2001)). Hence, nostalgia with selective and emotional perception/interpretation of the past has been associated with a valid opposition to real history - the so-called 'clear evidence' (Palmberger, 2008, p. 358). Stewart (1993) characterises it as a social disease, which establishes an emotionally charged relationship between an individual and the past; it reflects a love for the (idealised version of an unattainable) past, as well as stunting cultural imaginations by discounting and excluding real viable options; as well as a vehicle for xenophobia, anger, fear, hatred and anxiety (Volčič, 2007, p. 25), or other negative factors named by Rekść (2015, p. 106).

Nostalgia transforms history into entertainment, spectacle, and cultural fantasy (Jameson, 1991, p. 170). In contemporary Western capitalism, it is a part of the problem of a sense of alienation, a lack of historical consciousness, an inauthenticity (Jameson, 1997, p. 25), as well as a reaction to a fast moving and changing environment (Lowenthal, 1999; Palmberger, 2008). It is also a response to diverse personal needs, political desires (Tannock, 1995) and to disenchantment (Pickering and Keightley, 2006, p. 936). In this context, nostalgia is a side effect of contemporary progress, in which people with nostalgic feelings are stigmatised and labelled as an opposition to changes for a better life (Bonnett, 2010, p. 5). Consequently, individuals looking for spiritual fulfilment and having problems attaining it, are forced to escapism, the simple form of which is nostalgia (Umphlett, 2006, pp. 129-130).

Several complex postmodern aspects of nostalgia, linked to different kinds of experiences, led authors such as Havlena and Holak (1996), or Ekman and Linde (2005), to propose the following classification of nostalgic experiences:
1. personal nostalgia (direct individual experience);

2. interpersonal nostalgia (indirect individual experience);

3. cultural nostalgia (direct collective experience); and

4. virtual nostalgia (indirect collective experience).

The last two can also be understood in the context of collective/group nostalgia presented by Velikonja (2008, p. 26: see also Wildschut, Bruder, Robertson, van Tilburg and Sedikides, 2014) and Smeekes (2015). Velikonja (2008) divides nostalgia further into:

1. feeling/idea nostalgia, which is present in individuals and in their collective and individual memories of the past; and

2. materialised nostalgia, which is present through material objects, e.g. monuments, buildings and souvenirs.

The fall of the Berlin Wall marked the symbolic end of the communist regimes in the countries of Central and Eastern Europe. The consequences were mainly peaceful and democratic, but the disintegration of the SFRY is a bloody and cruel exception. The usual social transitions through democratisation, privatisation, marketisation and Europeanisation were marked by war in the case of the SFRY (Gilbert, 2006, p. 17). All of these processes impact attitudes towards recent history (and nostalgia) in the former communist states: see Todorova and Gille (2012), or Velikonja (2008) for further details. In this context, Ekman and Linde (2005) distinguished among four analytical dimensions of "communist nostalgia":

1. a political-ideological dimension;

2. socio-economic dimension;

3. personal socioeconomic dimension; and

4. personal biography dimension.

These authors claim that "communist nostalgia" as a multidimensional phenomenon, however, is more closely related to dissatisfaction with the present situation (in terms of performance indicators) in post-communist states than to genuine non-democratic values (Petrović, 2013, p. 107). Note that this is completely in line with the previous statements about individuals in postmodern society and explanations of the concept of nostalgia.

A number of authors have studied nostalgia in the former communist countries in Europe (see Tab. 1), where memory/longing for the old regime is present in the entire area but not everywhere to the same degree. The largest number of people favourable to the past epoch is found in Bulgaria, Romania and the former USSR, except the Baltic states (Ekman and Linde, 2005; Saarts, 2016), and in Hungary (Ekman and Linde, 2005; Rekść, 2015, p. 107). Nonetheless, in accordance with trends of the postmodern

\begin{tabular}{ll}
\hline Subject (former communist state) & Author(s) \\
\hline Former Yugoslavia (SFRY) & $\begin{array}{l}\text { Bancroft (2009); Bošković (2013); Hofman (2012); Lindstrom (2005); Palmberger (2008); } \\
\text { Pauker (2006); Segota and Jančič (2012; 2013); Simmons (2009); Sram (2001); Velikonja } \\
(2008) ; \text { Velikonja and Majsova (2014); Volčič (2007) }\end{array}$ \\
Union of Soviet Socialist Republics (USSR) & $\begin{array}{l}\text { Heady and Gambold Miller (2006); Holak et al. (2007); Holak et al. (2005); Mendelson } \\
\text { and Gerber (2005); Nikolayenko (2008); Oushakine (2007). }\end{array}$ \\
German Democratic Republic (GDR) & Bach (2002); Berdahl (1999); Boyer (2006) \\
People's Republic of Bulgaria & Creed (2006); Ivanov (2009) \\
\hline
\end{tabular}

Tab. 1: Research on nostalgia in selected post-communist countries Source: author's elaboration 
era, this kind of nostalgia is not in decline, which further justifies more research to close the gap in this field (Palmberger, 2008, p. 357). It is necessary to demystify life in Eastern Europe, which is usually seen as an exotic planet for West Europeans, as in the case of the Germany described by Boyer (2006).

Bošković (2013, p. 54) gave different names and shapes to nostalgia in post-communist societies, where nostalgia for socialism in the former SFRY is called Yugonostalgia. The phenomenon is coloured by several factors: on-going disputes among Partisan movement supporters, and those of the SFRY's internal enemies (Ustasha, Chetniks, and other anticommunists); historical revisionism and nationalism (see Ugrešić (1998) for more details); and widespread corruption and particularly difficult living conditions in some areas (Bancroft, 2009; Lindstrom, 2005). The term can be broadly defined as nostalgia for the fantasies associated with the SFRY (see Fig. 1). Any relationship between accurate and precise memories and facts of the past and present desires does not necessarily exist, as demonstrated by and through Yugonostalgic representations (Lindstrom, 2005, p. 233) It is nostalgia for a Yugoslav type of communism marked by some capitalist liberties, e.g. open borders, a passport that allowed them to travel abroad, foreign movies and a higher standard of living, which matters from a tourism point of view - see Tchoukarine (2010) and Tchoukarine (2015). It should be mentioned that not all citizens of post-SFRY states were able to travel abroad freely, e.g. to EU member states or to the USA and Australia. A similar term is Titonostalgia, as defined by Velikonja (2008, p. 31), which is a nostalgic discourse about the deceased SFRY President which arose after the disintegration of the federation.

The term Yugonostalgia came into existence in the 1990s in the post-SFRY area, and it usually has very negative connotations. To nationalists, it serves as negative label for all those intellectuals who once said something critical about the current regimes: they were/are termed to be Yugonostalgic, which means sceptics, public enemies and national traitors "who are guilty because they have publicly declared their anti-nationalist, anti-war and individual standpoint" (Pauker, 2006, pp. 77-78; Ugrešić, 1998, pp. 74, 77-78), and this was especially characteristic for Croatia (Ugrešić, 1998). In this context, Sram (2001) sees Yugonostalgia as part of four relatively independent latent dimensions of "socialist ideology", identifying Yugonostalgia with:

1. the need for the reconstruction of the former SFRY;

2. the glorification of Tito and the working class;

3 . the moral superiority of the former communist system; and

4. a preference for state-ownership.

Similarly, Simmons (2009, p. 458) presented it as (negative) "romanticising of Tito's SFRY of brotherhood and unity", which is in line with the afore-mentioned Titonostalgia.

Pančić (as quoted by Bošković, 2013, p. 77; see also Pauker, 2006, p. 79) offered the term normal-nostalgia as more appropriate than Yugonostalgia, because it reflects the desire for a normalisation of today's life that compels people to recall memories of the last period of "normality" they had experienced. Perhaps, as everyone, they are just nostalgic for the time of their childhood (Boyer, 2006, p. 372), which perfectly coincided with the end of SFRY, and their stories, memories and feelings are transmitted to the younger generations (Bancroft, 2009, pp. 11-12; Palmberger, 2008 , pp. 362, 366). This negates Volčič's (2007, p. 22) claim that Yugonostalgia, which romanticises the past, misses the point because it is not totally clear what people lost. Clearly, people are looking for a life that would be better than the present one: for many people of the former SFRY, faced with the present-day realities of extremely problematic socio-economic conditions, even with threatened existence, especially those in post-conflict areas with an ineffective public system marked by widespread corruption, any existence might appear to be better than the present - and this creates the conditions for escapism. This makes nostalgia a potential engine and means of emancipation, through which the public "[does] not restrict itself to criticism of the present world but also constructs an alternative world and aspires for the realisation of a different reality of existence" (Velikonja, 2008, p. 123).

The well-recognised Slovenian sociologist Rastko Močnik does not connect Yugonostalgia with the political idea of Yugoslavism. Bajer (as quoted by Rekść, 2015, p. 107) explains this phenomenon as the result of dramatic attempts of looking at one's identity and of a desire to be oneself in today's complicated reality, i.e. a question of identification and feeling of belonging. This is not the "result of the desire to return to the old regimes"; rather it is a lack of cultural alternatives that Slovenians find in other republics of the former SFRY (Bošković, 2013; Ilić, 2005; Velikonja, 2008). This is a similar argument to Boym's (2001; see also Lindstrom, 2005; Simmons, 2009, p. 460) reflective nostalgia, while according to Simmons (2009, p. 460), nationalism in the post-Communist states in general represents a restorative position. In contrast, for the Bosnian Croats of Mostar, Yugonostalgia is tantamount to betrayal or amnesia (Palmberger, 2008, p. 361), which could be generalised to the whole Croatian population following the explanations of Ugrešić (1998). Similarly, Šram (2001) claims that, in addition to Croatians, residents of the Vojvodina region in Serbia also share fewer Yugonostalgic feelings. These (often overlapping) aspects of Yugonostalgia, however, are now evident in the region:

1. revisionist nostalgia is primarily a political phenomenon, where the main problem is historical revisionism for political purposes (see also Oushakine, 2007);

2. aesthetic nostalgia is primarily a cultural phenomenon calling for the preservation of an authentic SFRY past, but not exploited for political or commercial gain; and

3. escapist, utopian nostalgia is a commercial phenomenon that celebrates and exploits the longing for an idyllic SFRY, regardless of facto-graphic history (Volčič, 2007, p. 28), and it is often used for tourist purposes.

Some other forms are identified in Lindstrom (2005) and Velikonja (2008).

\section{Contemporary tourism and Yugonostalgia}

The connection between nostalgia and tourism is not something new. At the beginning of $18^{\text {th }}$ century Jean-Jacques Scheuchzer provided a mechanical and physical explanation for the favourable effect of Swiss Alpine climate on nostalgia. These conditions were advantageously placed into the tourist promotional material of accommodation providers (Starobinski, 2009, p. 62). Today we have a completely different attitude toward nostalgia, however, since we link it with travelling, especially in an escape-seeking dichotomy perspective (Yoon and Uysal, 2005), where a tourist is pushed by innate motives to travel and pulled by destination-specific 
attributes in the decision-making phase (Ryan et al., 2010; Yoon and Uysal, 2005). Tourists are looking for historical and heritage destinations that attract them with nostalgic motives, but do not directly impact on their loyalty (Leong et al., 2015). Hence, this historicised, linearised narrative offers an authentic experience, although, for example, museums also host a wide range of cultural and social events that do not have much to do with heritage, but may impact the local economy and cultural life (Petrović, 2013, pp. 104105), which is also a general characteristic of tourism.

A remnant of the Berlin Wall is one of the largest worldlevel tourist attractions, where tourists can not only experience and contemplate history but also buy souvenirs. The former GDR has a good marketing strategic approach as evidenced by the amount of tourism services inspired by the culture of the past in Germany (Frey, 2015). In addition, nostalgia and memory become detached from political and historical life in order to be packaged and sold for a good price: the era of the SFRY is re-written and re-packaged for promotion and resale, and hence the denial of responsibility for the wars in the 1990s and their consequences is enabled to be continued (Volčič, 2007, pp. 34-35).

The commercialisation of the symbols of the SFRY is the single most visible aspect of the Yugonostalgia phenomenon, which quickly drew the attention of academic researchers as well as the wider public (Kurtović, 2011, p. 8). Tito's image and name are therefore evaluated by the market and can be understood as a brand or trademark, not to mention the many other cases of the occurrence of his figure and name in the culture, politics and everyday life in general. In Slovenia, he "helped" to sell cars, as well as wine in Croatia, mineral water in Serbia and Macedonia, and neckties in Bosnia (Volčič, 2007). This means that historical nostalgia influences consumer attitudes: see Marchegiani and Phau (2011), Merchant and Rose (2013), and Muehling (2013) for further details.

In this tourist-commercial context, Velikonja (2008) listed many tourism-related examples of attractions: Kumrovec, Drvar, Jajce, Vis and the Brijuni Islands, the House of Flowers mausoleum in Belgrade, not to mention many hospitality facilities throughout the former federation. Also, he demonstrates significant links between tourism and Yugonostalgia, denoting this type of tourism as "Titotourism", for which Slovenian tourists are among the most recognisable in the territory of the former SFRY (see Tab. 2). As in the case of Slovenia and Croatia, however, significant geographical, political and economic connections between the states have resulted in a certain image of Croatia as a tourist destination for Slovenians (Konečnik, 2005; Šegota and Jančič, 2013). Slovenian tourists are not homogeneous in relation to their perceptions of Croatia's tourism services. Rather they are members of one of four clusters who labelled themselves as Yugonostalgics (Šegota and Jančič, 2013), which is in line with these authors' previous research (Šegota and Jančič, 2012). Therefore, the figures in Table 2 clearly demonstrate the importance of Slovenian tourists for tourism destinations of the former SFRY.

\begin{tabular}{|c|c|c|c|c|c|c|c|}
\hline State & 2016 & 2015 & 2014 & 2013 & 2012 & 2011 & 2010 \\
\hline \multicolumn{8}{|l|}{ Serbia $^{1}$} \\
\hline No. of arrivals & 74,096 & 65,756 & 64,389 & 67,498 & 65,723 & 74,674 & 66,686 \\
\hline$\%$ of $\mathrm{FT}^{*}$ & 5.78 & 5.81 & 6.26 & 7.32 & 8.11 & 9.77 & 9.77 \\
\hline Importance $* *$ & 6 & 4 & 2 & 3 & 1 & 1 & 1 \\
\hline \multicolumn{8}{|l|}{ Croatia $^{2}$} \\
\hline No. of arrivals & $1,298,501$ & $1,192,000$ & $1,101,552$ & $1,067,000$ & $1,054,000$ & $1,100,000$ & $1,017,000$ \\
\hline$\%$ of FT & 10.24 & 9.40 & 9.48 & 9.75 & 10.16 & 11.08 & 11.16 \\
\hline Importance & 2 & 2 & 2 & 2 & 2 & 2 & 2 \\
\hline \multicolumn{8}{|l|}{ Montenegro $^{3}$} \\
\hline No. of arrivals & 18,418 & 19,533 & 16,794 & 16,651 & 18,463 & 18,550 & 22,475 \\
\hline$\%$ of FT & 1.11 & 1.25 & 1.24 & 1.26 & 1.46 & 1.54 & 2.07 \\
\hline Importance & 15 & 14 & 12 & 16 & 14 & 14 & 11 \\
\hline \multicolumn{8}{|c|}{ Bosnia and Herzegovina ${ }^{4}$} \\
\hline No. of arrivals & 50,448 & 45,635 & 39,523 & 42,019 & 39,949 & 41,267 & 40,246 \\
\hline$\%$ of FT & 6.50 & 6.73 & 7.37 & 7.95 & 9.11 & 10.53 & 11.01 \\
\hline Importance & 5 & 6 & 5 & 4 & 3 & 3 & 3 \\
\hline \multicolumn{8}{|l|}{ FYR Macedonia ${ }^{5}$} \\
\hline No. of arrivals & 9,971 & 11,463 & 14,486 & 13,404 & 13,252 & 14,063 & 12,606 \\
\hline$\%$ of FT & 1.95 & 2.36 & 3.40 & 3.35 & 3.77 & 4.29 & 4.82 \\
\hline Importance & 13 & 12 & 10 & 7 & 8 & 6 & 7 \\
\hline
\end{tabular}

Tab. 2: Slovenians as foreign tourists in the markets of the former SFRY (Note: *share of Slovenian tourists in the group of foreign tourists (FT) in the country; ** place in the (national) structure of foreign tourists)

Sources: ${ }^{1}$ Statistical Yearbook of the Republic of Serbia 2017 (2017, p. 380), ${ }^{2}$ Statistical Yearbook of the Republic of Croatia 2016 (2016, p. 439); Priopćenje/First release (2017); ${ }^{3}$ Statistical Yearbook 2016 (2016, p. 148), Statistical Yearbook 2017 (2017, p. 146), ${ }^{4}$ Saopštenja (Press) (2017, 2015, 2010), ${ }^{5}$ Statistical Yearbook of the Republic of Macedonia, 2017 (2017, pp. 588-589); Statistical Yearbook of the Republic of Macedonia, 2015 (2015, 2015, pp. 598-599) 
Nostalgia/Yugonostalgia is only one reason for tourism engagement, which entirely corresponds to thematic tourism theory (Douglas, Douglas and Derrett, 2001; Rabotić, 2014). Terms such as "niche tourism" (Robinson and Novelli, 2005), "selective forms of tourism" (Štetić, Šimičević and Curčić, 2013), or "special interest tourism" (Douglas, Douglas, and Derrett, 2001) are also used. Wong and Cheung (1999) propose that tourists seek personally adjusted tourist experiences, including immaterial qualities, a sense of inner fulfilment, emotions and satisfaction, in response to the depersonalisation and rationalisation of postmodern urban life (Trauer, 2006). Consequently, countless possibilities for tourist engagement are present in the market (see Douglas et al., 2001; Kruja and Gjyrezi, 2011; Štetić et al., 2013; Trauer, 2006), and these are reflected in the number of tourist products.

In turn, the latter can be grouped in the following product families: pleasure; personal quest; human endeavour; nature; and business (McKercher, 2016). There has been little academic research attempting to determine which thematic products motivate Slovenian tourists to visit destinations of the former SFRY (see Fig. 1). Yugonostalgia is often discussed in scientific papers and books, particularly in the general or conceptual sense or in terms of society, politics and arts (culture), while tourism-related issues occur only rarely. Therefore, in this study, we examine the views of Slovenians in relation to nostalgia and other touristic reasons for travelling to destinations of the former SFRY. More specifically, the main proposition of this study is: "Slovenian tourists are Yugonostalgic and very heterogeneous in their views on reasons for their journeys to destinations of the former SFRY, which implies that they can be categorised into several clusters".

\section{Methodology}

A web questionnaire pertaining to Slovenian tourists' perceptions was initially developed from previous relevant research (Douglas et al., 2001; McKercher, 2016; Šegota and Jančič, 2013; Štetić et al., 2013; Velikonja, 2008). The questionnaire was focused on different perspectives of nostalgia, Yugonostalgia and tourism, and was (innately) technically tested on a sample of 500 computer-completed questionnaires by using a specialised web application. In the second step, a pilot interview with four experts in tourism was conducted. Consequently, the questionnaire was technically and substantially improved. In order to represent the population structure of tourists with SFRY travel experience, respondent-driven sampling was used; this type of sampling is particularly applicable when the focus is on subtle issues and/or when members of the specific populations have not all been previously identified so-called 'hidden populations' (Johnston and Sabin, 2010; Spiller, Gile, Handcock, Mar and Wejnert, 2017).

A group of 50 potential respondents, for which we had relevant information about their travel habits, was initially contacted and invited to share the questionnaire with their acquaintances. Special attention was put on the initial sample size with the heterogenous respondents in order to avoid unstable estimates and to approximate random sampling (see Snijders, 1992, pp. 68-69; Frank and Snijders, 1994, p. 66; Johnston and Sabin, 2010). The initial sample was stratified (this approach is suggested by Snijders, 1992), where three demographic characteristics were used: education, nationality and age. Thus, some kind of "irregular network" of respondents in Slovenia, where every previous respondent knows the travel habits of the next, was formed. A total of 520 questionnaires were collected in 31 days in the spring of 2016, and 384 were appropriate for analysis (missing responses represented less than $30 \%$ of the questionnaires).

The questionnaire started with a screening question asking whether the respondent had visited former SFRY destinations, in order to exclude respondents with no SFRY travel experience from the research. As described in section 2, "Nostalgia and Yugonostalgia", consumers or just lovers of attractions in the former SFRY destinations can be harder-to-reach because they (may) exhibit some kind of social stigma. Therefore, it is difficult to identify them as "SFRY-oriented tourists" in the population and include them in the research, although they are not few in number.

The questionnaire, which was available in the Slovenian language, consisted of three sections. The first section contained 17 items of reasons for visiting, on 5-point Likert-type scales, in which "1" means "strongly disagree" and " 5 " means "strongly agree". In the second section, respondents were asked what they think about tourism services available in the former SFRY, about impacts on the decision for travelling, and about Yugonostalgia; a total of five items were chosen and included in the questionnaire for additional clarification of the impacts on the decision undertaken by visitors. The last section examined the demographic characteristics of Slovenian visitors.

The collected data were analysed employing SPSS version 20.0. Both hierarchical and non-hierarchical clustering methods were used to identify clusters. Using a descriptive approach, the comparison between clusters was undertaken to analyse and describe the groups' characteristics. In addition, cross-tabulations were employed to profile each cluster based on demographic characteristics and the identified groups or clusters; chi-square tests were performed to validate the clusters and their mutual differences (at the 0.05 level of significance). Significant differences between groups with respect to the various items were verified by One-way Analysis of Variance, with post-hoc Tukey's HSD test (for unequal numbers in groups), given that the overall model was significant.

Regarding the sample profile, Table 3 summarises the demographic profile of the final set of respondents. They mainly belong to the post-1991 generation (the period of the disintegration of SFRY), although they were relatively evenly spread across all age groups. This is interesting in terms of the transmission of Yugonostalgic feelings among generations in order to influence descendants' understandings of the SFRY period. The educational structure shows that $56 \%$ of respondents finished High school or Professional secondary school $\left(2^{\text {nd }}\right.$ level). Among the respondents, $75 \%$ of the sample was female (this ratio is hard to explain as a result of the respondent-driven sampling); most respondents (75.8\%) were Slovenians, 9.3\% were Bosniaks, and 'others' (minority nations of the former SFRY) represent less than $4 \%$ of the total. This structure is a reflection of the past and present migration flows within the former SFRY. In addition, respondents would mostly recommend a visit to Bosnia and Herzegovina (39.4\%) and Serbia (37.7\%), while Croatia is in a distant third place $(13.2 \%)$. Considering the heterogeneous structure of the initial sample and, consequently, the realised final sample, we estimated that further analysis was quite reasonable. 


\begin{tabular}{|c|c|c|c|c|c|c|}
\hline Demographic characteristic & $\Sigma$ & Cluster 1 & Cluster 2 & Cluster 3 & $\chi \mathbf{2}$ & Sig. (2-sided) \\
\hline \multicolumn{7}{|l|}{ Gender } \\
\hline Male & 89 & 24 & 36 & 29 & 1.74 & 0.419 \\
\hline Female & 267 & 91 & 92 & 84 & & \\
\hline \multicolumn{7}{|l|}{ Education (finished) } \\
\hline Elementary & 24 & 15 & 4 & 5 & 20.539 & 0.008 \\
\hline Professional secondary & 62 & 15 & 26 & 21 & & \\
\hline High school & 139 & 47 & 54 & 38 & & \\
\hline Vocational school, college or university & 101 & 30 & 38 & 33 & & \\
\hline Master or PhD & 30 & 8 & 6 & 16 & & \\
\hline \multicolumn{7}{|l|}{ Nationality } \\
\hline Slovenian & 270 & 99 & 64 & 107 & 80.239 & 0.000 \\
\hline Serbian & 27 & 4 & 22 & 1 & & \\
\hline Croatian, Macedonian and Montenegrin* & 12 & 3 & 7 & 2 & & \\
\hline Bosniak & 33 & 6 & 27 & 0 & & \\
\hline Other & 14 & 3 & 8 & 3 & & \\
\hline \multicolumn{7}{|l|}{ Year of birth } \\
\hline Before 1950 & 2 & 0 & 1 & 1 & 30.651 & 0.002 \\
\hline 1951 to 1960 & 15 & 2 & 7 & 6 & & \\
\hline 1961 to 1970 & 47 & 7 & 13 & 27 & & \\
\hline 1971 to 1980 & 57 & 21 & 16 & 20 & & \\
\hline 1981 to 1990 & 38 & 9 & 16 & 13 & & \\
\hline 1991 to 2000 & 194 & 76 & 73 & 45 & & \\
\hline 2001 and over & 1 & 0 & 1 & 0 & & \\
\hline
\end{tabular}

Tab. 3: Demographic characteristics of the three clusters of respondents (Note: *merged into one group with $\sum>10$. Not all respondents responded to all demographic questions)

Source: author's calculation

\section{Results and discussion}

A descriptive analysis showed that $83.0 \%$ of respondents repeatedly returned to the destination or state they had visited in the past, which means that they are loyal visitors to former SFRY destinations, although they rate the tourist services there as being of average attractiveness on the 5 -point scales ( $\overline{\mathrm{x}}=3.44 ; \mathrm{Me}=3.00 ; \mathrm{Mo}=3.00 ;$ respectively, mean, median and mode); this is also typical for the members of each single cluster from Table 4. Therefore, Yugonostalgia has only an average $(\overline{\mathrm{x}}=2.77)$ impact on their final decision, since $46.8 \%$ of respondents believe that Slovenians are not more Yugonostalgic than other nations of the former SFRY (31.8\% of them chose the answer "do not know"). In this respect, it is necessary to take into consideration that the negative connotation of the phenomenon would impact the answers to direct questions. This is completely in line with the findings of Rekść (2015, p. 107) and Ekman and Linde (2005), who claim that the lowest number of people declaring their longing for the past epoch can be found in countries such as Slovenia and the Czech Republic.

In the next step, we wanted to check the reliability of the included variables. The reliability of the items was confirmed with a Cronbach's $\alpha$ value of 0.815 . In addition, we calculated the coefficients of skewness and kurtosis for the included variables: $-1.632 \leq \gamma 1 \geq 1.412$ and $-1.666 \leq \beta 2 \geq 2.793$ (the majority is included in the interval from -0.8 to 0.8 ). We also calculated the $95 \%$ confidence intervals for the means: Sig. (2-tailed) amounted 0.000 for all variables. After that, 17 variables were used in a cluster analysis to identify groups with different views and attitudes toward visiting former SFRY destinations; hierarchical and non-hierarchical cluster analyses were employed to segregate responses into mutually exclusive groups. First, a hierarchical procedure using Ward's principal component score method was employed to obtain a starting point in establishing the number of clusters. As a result, a three-cluster solution was identified. Second, the three-cluster solution was used in non-hierarchical analysis (K-means clustering). To label and delineate the identified clusters, the mean scores for each item were computed, and the results are analytically presented in Table 3 and Table 4.

The usual reasons for individuals travelling in postmodern society, such as relaxation and rest and escaping from daily routine, are important characteristics of all clusters identified, which is completely in line with Trauer (2006), Stetić et al. (2013) and Yoon and Uysal (2005), but not according to the other items (Tab. 4), with the escapist, utopian nostalgia reason introduced by Volčič (2007). Respondents are obviously completely indifferent to socialism/communism and they would not visit destinations for health reasons either. They are slightly more favourable toward the former SFRY, but on the basis of the mean values $(1.52 \leq \overline{\mathrm{x}} \leq 2.86)$, they cannot be labelled as Yugonostalgic. Memories of the common state obviously do not sell in the 
Slovenian source market, as Volčič (2007) claims in the case of Tito's name and figure. This finding in some way negates the link between tourism and Yugonostalgia explained by Velikonja (2008) and Šegota and Jančič (2012; 2013). But we do believe that target groups more susceptible to SFRY exist in the market (e.g. veterans organisations) for which Yugonostalgic aspects should be explored in the future. In contrast, natural conditions (attractions) are another common reason for travelling, which is consistent with the findings of Šegota and Jančič $(2012 ; 2013)$ or Douglas et al. (2001; see also Štetić et al., 2013). It should also be emphasised that the first four items in Table 4 represent the kind of motivators that are related to all other items, which can be transformed into tourist products.

The individual clusters can now be described in more detail:

a. Cluster 1 members represent one third of the entire sample (Table 4) and score low on supporting 11 reasons for travelling to the former SFRY destinations $(1.28 \leq \overline{\mathrm{x}} \leq 2.25)$, although they identified themselves as returning tourists. All rejected reasons for travelling originate in the thematic tourism theory (see Douglas et al., 2001; McKercher, 2016; Štetić et al., 2013).
They are slightly more favourable to cultural and entertaining content, although even this orientation is only average. Cluster members obviously want to escape and relax in nature, which indicates that they can be called Friends of nature. On the basis of these characteristics, they can be compared to the cluster named Sensitive enthusiasts identified by Šegota and Jančič (2013). Cluster 1 differs most significantly from the other two clusters. Of the 51 comparisons in Table 4, only for three of them are the 'same' for Cluster 1 and another cluster (see Tab. 4).

b. Cluster 2 members demonstrate much more sympathy to the offer of former SFRY destinations $(0.000 \leq p \leq 0.008)$. Beside the love of nature and the related relaxation (they have the highest $\bar{x}$ ), they are very interested in cultural- and sports-oriented events, entertainment and food and beverage; their average ratings are the highest for the majority of all variables. In comparison with the members of Clusters 1 and 3, only members of Cluster 2 visit their relatives in the former SFRY area $(p=0.000)$, which is related to the so-called roots tourism (for more details, see Koderman, 2012; Koderman and Mihelič Pulsipher, 2012). Furthermore,

\begin{tabular}{|c|c|c|c|}
\hline \multirow{2}{*}{ Reason } & \multicolumn{3}{|c|}{ Cluster* } \\
\hline & $1(\mathrm{n}=125)$ & $2(\mathrm{n}=139)$ & $3(\mathrm{n}=120)$ \\
\hline Relaxation and rest & $4.21 \mathrm{a}$ & $4.49 \mathrm{~b}$ & $4.17 \mathrm{a}$ \\
\hline Longing for the former common state & $1.52 \mathrm{a}$ & $2.86 \mathrm{~b}$ & $2.50 \mathrm{c}$ \\
\hline Longing for socialism/communism & $1.28 \mathrm{a}$ & $2.32 \mathrm{~b}$ & $2.33 \mathrm{~b}$ \\
\hline Escape from daily routine & $3.58 \mathrm{a}$ & $4.23 \mathrm{~b}$ & $4.12 \mathrm{~b}$ \\
\hline Education & $1.54 \mathrm{a}$ & $2.80 \mathrm{~b}$ & $2.68 \mathrm{~b}$ \\
\hline Natural conditions (attractions) & $3.96 \mathrm{a}$ & $4.49 \mathrm{~b}$ & $4.36 \mathrm{~b}$ \\
\hline Visits to cultural events & $2.25 \mathrm{a}$ & $3.53 \mathrm{~b}$ & $3.45 \mathrm{~b}$ \\
\hline Visits to museums, galleries, monuments, etc. & $2.51 \mathrm{a}$ & $3.47 \mathrm{~b}$ & $3.68 \mathrm{~b}$ \\
\hline Supply of food and beverages & $3.20 \mathrm{a}$ & $4.39 \mathrm{~b}$ & $4.26 \mathrm{~b}$ \\
\hline Entertainment & $3.46 \mathrm{a}$ & $4.45 \mathrm{~b}$ & $4.25 \mathrm{~b}$ \\
\hline Religious reasons & $1.36 \mathrm{a}$ & $2.53 \mathrm{~b}$ & $1.45 \mathrm{a}$ \\
\hline Visits to graves and other remnants of the conflict in $1990 \mathrm{~s}$ & $1.43 \mathrm{a}$ & $2.78 \mathrm{~b}$ & $2.28 \mathrm{c}$ \\
\hline Health & $1.33 \mathrm{a}$ & $2.12 \mathrm{~b}$ & $1.43 \mathrm{a}$ \\
\hline Visits to of relatives & $2.06 \mathrm{a}$ & $4.32 \mathrm{~b}$ & $1.53 \mathrm{c}$ \\
\hline Socialising and meeting friendly and hospitable locals & $2.47 \mathrm{a}$ & $4.23 \mathrm{~b}$ & $4.23 \mathrm{~b}$ \\
\hline Visits to sports events (including active participation) & $1.71 \mathrm{a}$ & $3.67 \mathrm{~b}$ & $2.52 \mathrm{c}$ \\
\hline Business & $1.47 \mathrm{a}$ & $2.65 \mathrm{~b}$ & $2.18 \mathrm{~b}$ \\
\hline
\end{tabular}

Tab. 4: Clusters of respondents (Note: *Means with the same letter do not differ significantly (Tukey's HSD, $p<0.05, n=384$ )

Source: author's calculation

\begin{tabular}{lccccc}
\hline Item and rate & Cluster 1 & Cluster 2 & Cluster 3 & $\chi_{\mathbf{2}}$ & \multicolumn{2}{c}{ Sig. (2-sided) } \\
\hline Relative short distance to the target destination & 3.94 & 3.91 & 4.12 & 6.218 & 0.623 \\
Good transport links with the various means of transport & 3.27 & 3.56 & 3.58 & 4.096 & 0.848 \\
Knowledge of language & 3.25 & 4.46 & 4.06 & 54.780 & 0.000 \\
Small cultural differences & 2.69 & 3.89 & 3.78 & 44.185 & 0.000 \\
Quality of local services & 2.51 & 2.61 & 3.63 & 66.899 & 0.000 \\
\hline
\end{tabular}

Tab. 5: Clusters of respondents according to a baseline for decision making Source: author's calculation 
socialising and meeting friendly and hospitable locals is another of their tourist activities, which additionally confirms the importance of social interactions for this variable, which was significantly different only compared to Cluster $1(\mathrm{p}=0.000)$. In the context of the listed characteristics, members of this, the largest, cluster in the sample could be identified as Immigrants and their descendants - originating in the five South Eastern republics of the former SFRY (see also national structure in Tab. 3). Not surprisingly, language knowledge and small cultural differences help them when they decide to travel. On the other hand, in transport-related variables they are not significantly different from more nationally homogeneous Clusters 1 and 3 (see national structure in Tab. 3 and Tab. 5).

c. Cluster 3: this last cluster consists of Moderate lovers of nature and culture, who, beside all the already defined common characteristics, identified with visiting museums, galleries, monuments, etc., and the consumption of food and beverages (e.g. education, introduction to authentic local gastronomy, pleasure and similar items) and entertainment. This feature clearly reflects their cultural requirements when travelling; further discussion of cultural tourism can be found in Gržinić and Vodeb (2015) or OECD (2008). Socialising and meeting friendly and hospitable locals is part of the wider field of ethnicity and ethnic relations, usually understood as guest-host relationships with strong commercial connotations (Cohen, 1984). This item is an important element for members of this cluster, because in this way they could encounter the everyday life of local residents and their culture. Although they are significantly different compared to members of Cluster 1 members, they are, on the other hand, broadly similar to Cluster 2 members (see Tab. 4). The latter have certain different understandings of the destinations they visit: identity consolidation, strengthening of language skills (see also Tab. 5), discovering ancestral heritage, searching for emotional experiences and similar items distinguish the journeys of Cluster 2 members: for more details, see Koderman (2012), or Koderman and Mihelič Pulsipher (2012).

The identified clusters are also different with respect to demographic data (Tab. 3), for which there are especially interesting differences in national origins and the age distribution. From this research, gender is not a differentiating category. In addition, we identified a baseline for the decision to set out on a journey (towards the "southern destinations") across different clusters (Tab. 5), where figures show that respondents recognise these baselines as relevant. Clusters are significantly different only in the items related to the knowledge of language, cultural differences and quality of local services $(\mathrm{p}=0.000)$ :

1. the significant difference among all clusters (verified by One-way ANOVA with post-hoc Tukey HSD tests), are identified only in the item related to the knowledge of language; and

2. Cluster 1 members differ most significantly from the other two clusters once again - with the exception of the transport-related variables. On the other hand, Cluster 2 members with their positive attitudes should be reviewed again. The presence of immigrant groups from the former SFRY in Slovenia (obviously) also has a tourist connotation in terms of the so-called roots tourism. Given their large numbers, heterogeneity and social status (see Kržišnik-Bukić, 2008; KržišnikBukić, Josipovič, Rizman and Žitnik Serafin, 2014), an evaluation of their tourism potentials would appear to be essential.

\section{Conclusions}

Many authors (e.g. Velikonja, 2008; Lindstrom, 2005; Volčič, 2007; Ugrešić, 1998) highlight Yugonostalgia in the former SFRY today in multiple forms, from restorative incarnations to more reflective varieties and, although slightly neglected, tourism represents a significant part of this phenomenon. Just as the six dominant nations that formed the former SFRY have their own experiences of the post-communist/post-socialist era, post-conflict recovery and (present) highly complex interethnic relations, various expressions and reflections of Yugonostalgia today have different manifestations in and impacts on tourism. In the context of so-called thematic tourism, some selected examples of reasons for travelling to former SFRY destinations, including those related to the former federation and its political system, were employed to identify different groups of Slovenian tourists. Although the former SFRY is today (mainly) perceived as an incomprehensible mixture of incompatible nations, religions or cultures (Bakić-Hayden and Hayden, 1992; Lindstrom, 2005; Ugrešić, 1998), it is not so negatively perceived in terms of contemporary tourism, which offers good predispositions for the development of the cross-border travel (see Tab. 2).

Based on this empirical research, three significantly different clusters of Slovenian visitors were identified: all of them were completely indifferent to the former common federation and socialism/communism, although all of them are regular visitors to former SFRY destinations - the label Homo Iugoslovanicus consequently - is not correct. Various other reasons that were important for their travel practices were identified, which is already known from the theory of thematic tourism in general. Obviously, the Slovenian outgoing tourists behave just like other conventional tourists do. Is this the hybrid and satirical neo-nostalgia, as defined by Velikonja (2008)? The answer to this question will be provided in future research.

The main proposition in this project can be confirmed only partly: the heterogeneity of the tourists is not in question, but their Yugoslav feelings are counter to those hypothesised, with low average ratings (e.g. 'longing for the former common state' [1.52 $\leq \overline{\mathrm{x}} \leq 2.86$ ], or 'longing for socialism or communism' [1.28 $\leq \overline{\mathrm{x}} \leq 2.33]$ ) clearly showing their views, although significant statistical differences do exist among all three defined clusters (except for the socialism/communism item, where clusters 2 and 3 are the same). In terms of the findings of this research, verses of the previously-mentioned song "Yugoslavia" (Jugoslavijo) that relate to the revolution and socialism, should be defined as not relevant today. Much more relevant are the obvious nature, culture, relaxation options, family relationships and other reasons for travelling, although even for these items, Slovenian residents do not demonstrate the same attitudes (see Tabs. 4 and 5).

The results reported here are only representative for the respondents included in the sample (travellers to the postSFRY destinations), which is one of the survey's limitations. On the other hand, according to the explanations of Snijders (1992, p. 69; see also Atkinson and Flint, 2001), 
we can conclude that, because of the relatively large initial sample with heterogeneous structure (stratified sample), the findings may be much closer to reality than those based on a simple random sample. Another limitation is the involvement of respondents who have access to the Internet and were interested in cooperating (the link to the online questionnaire was sent to each individual [potential] respondent); this is not so self-evident because of their potential ignorance, resistance and/or protest, although selection bias is always possible. In addition, the homogenous national structure of the sample, where a sufficient proportion of other nations (immigrants) was, however, included, did not allow performing additional analyses with newer interesting findings. This project can be seen as economically and efficiently implemented research (financial resources were very limited) on a specific tourism segment with clear indicative significance. With this first quantitative research oriented toward the former SFRY, some of the stereotypes and general judgments about Yugonostalgic Slovenian tourists and some views of Yugonostalgia based on conceptual definitions or qualitative research, have been refuted. The main types of Slovenian tourists and their (tourist) preferences related to the post-SFRY countries are now identified in a scientifically sound manner for the postcommunist/post-socialist contexts.

\section{References:}

ARNOULD, E. J., PRICE, L. L. (1993): River Magic: Extraordinary Experience and the Extended Service Encounter. Journal of Consumer Research, 20(1): 24-45.

ATKINSON, R., FLINT, J. (2001): Accessing hidden and hard-to-reach populations - Snowball research strategies: University of Surrey Social Research Update. [cit. 11.11.2017]. Available at: http://sru.soc.surrey.ac.uk/ SRU33.htm

BACH, J. P. G. (2002): 'The Taste Remains': Consumption, (N)ostalgia, and the Production of East Germany. Public Culture, 14(3): 545-556.

BAKIĆ-HAYDEN, M., HAYDEN, M. R. (1992): Orientalist variations on the theme 'Balkans': Symbolic geography in Yugoslav cultural politics since 1987. Slavic Review, 5(1): $1-15$.

BANCROFT, C. (2009): Yugonostalgia: The Pain of the Present. [cit. 17.12.2016]. SIT Graduate Institute website. Available at: http://digitalcollections.sit.edu/ isp_collection/787

BERDAHL, D. (1999): '(N)Ostalgie' for the Present: Memory, Longing, and East German Things. Ethnos, 64(2): 192211.

BERGER, H., DENK, M., DITTENBACH, M., MERKL, D., PESENHOFER, A. (2007). Quo Vadis Homo Turisticus? Towards a Picture-based Tourist Profiler. In: Sigala, M., Mich, L., Murphy, J. [eds.]: Information and Communication Technologies in Tourism 2007 (pp. 87-96). Wien, Springer.

BILOSLAVO, R., KLJAJIĆ-DERVIĆ, M. (2016): Dejavniki uspešnosti managementa znanja: primer trgovine v državi $\mathrm{v}$ razvoju. Koper, Založba Univerze na Primorskem.

BONNETT, A. (2010): Left in the Past: Radicalism and the Politics of Nostalgia. New York, Continuum International Publishing Group.
BOŠKOVIĆ, A. (2013): Yugonostalgia and Yugoslav Cultural Memory: Lexicon of $\underline{\mathrm{Yu}}$ Mythology. Slavic Review, 72(1): 54-78

BOYER, D. (2006): Ostalgie and the Politics of the Future in Eastern Europe. Public Culture, 18(2): 361-382.

BOYM, S. (2001): The Future of Nostalgia. New York, Basic Books.

BOYM, S. (2007): Nostalgia and its Discontents. Hedgehog Review, 9(2): 7-18.

CARDWELL, S. (2002): Adaptation Revisited: Television and the Classic Novel. Manchester, Manchester University Press.

CHEN, H.-B., YEH, S.-S., HUAN, T.-C. (2014): Nostalgic emotion, experiential value, brand image, and consumption intentions of customers of nostalgic-themed restaurants. Journal of Business Research, 67(3): 354-360.

COHEN, E. (1984): The Sociology of Tourism: Approaches, Issues, and Findings. Annual Review of Sociology, 10: 373-392.

CREED, G. (2006): Domesticating discontent: The work of nostalgia in Bulgaria. In: Conference Post-Communist Nostalgia. University of Illinois, Urbana - Champaign, April 7-8, 2006.

DOUGLAS, N., DOUGLAS, N., DERRETT, R. [eds.] (2001): Special interest tourism: context and cases. Melbourne, John Wiley \& Sons Australia.

EKMAN, J., LINDE, J. (2005): Communist nostalgia and the consolidation of democracy in Central and Eastern Europe. Journal of Communist Studies and Transition Politics, 21(3): 354-374.

FRANK, O., SNIJDERS, T. (1994): Estimating the Size of Hidden Populations Using Snowball Sampling. Journal of Official Statistics, 10(1): 53-67.

FREY, M. (2015): Postwall German Cinema: History, Film History and Cinephilia. Oxford-New York, Berghahn Books.

GILBERT, A. (2006): The past in parenthesis: (Non)postsocialism in post-war Bosnia-Herzegovina. Anthropology Today, 22(4): 14-18.

GRŽINIĆ, J., VODEB, K. [eds.] (2015): Cultural tourism and destination impacts. Pula, Juraj Dobrila University of Pula.

HEADY, P., GAMBOLD MILLER, L. L. (2006): Nostalgia and the emotional economy: a comparative look at rural Russia. In: Svašek, M. [ed.]: Post socialism: politics and emotions in Central and Eastern Europe (pp. 34-52). New York, Berghahn Books.

HAVLENA, W. J., HOLAK, S. L. (1996): Exploring Nostalgia Imagery Through the Use of Consumer Collages. In: Corfman, P. K., Lynch, G. J. [eds.]: NA - Advances in Consumer Research (Vol. 23, pp. 35-42). [cit. 17.11.2016]. Provo, Association for Consumer Research. Available at: http://acrwebsite.org/volumes/7864/volumes/v23/NA-23

HOFMAN, A. (2012): Lepa Brena: Repolitization of musical memories on Yugoslavia. Glasnik Etnografskog Instituta SANU, 60(1): 21-32.

HOLAK, L. S., MATVEEV, V. A., HAVLENA, J. W. (2007): Nostalgia in post-socialist Russia: Exploring applications to advertising strategy. Journal of Business Research, 61(2): 172-178. 
HOLAK, S., HAVLENA, W., MATVEEV, A. (2005): Exploring Nostalgia in Russia: Testing the Index of NostalgiaProneness. In: Ekstrom, M. K., Brembeck, H. [eds.]: E - European Advances in Consumer Research (Vol. 7, pp. 195-200). [cit. 20.12.2016]. Goteborg: Association for Consumer Research. Available at: http://acrwebsite.org/ volumes/13747/eacr/vol7/E-07

ILIĆ, A. (2005): Slovenac više ne postoji. [cit. 17.12.2016]. Večerne Novosti. Available at: http://www.novosti.rs/ vesti/naslovna/drustvo/aktuelno.290.html:167708Slovenac-vise-ne-postoji

IVANOV, S. H. (2009): Opportunities for Developing Communist Heritage Tourism in Bulgaria. Tourism, 57(2): 177-192.

JAMESON, F. (1991): Postmodernism, or The Cultural Logic of Late Capitalism. Durham, N. C., Duke University Press.

JAMESON, F. (1997). Postmodernism and consumer society. In: Brooker, P., Brooker, W. [eds.]: Postmodern after-images: A reader in film, television and video (pp. 22-30). London, Arnold.

JERŠIČ, M. (1985): Turistična geografija. Ljubljana, Univerza Edvarda Kardelja v Ljubljani, Filozofska fakulteta, Oddelek za geografijo.

JOHNSTON, L. G., SABIN, K. (2010): Sampling hard-toreach populations with respondent driven sampling. Methodological Innovations Online, 5(2): 38-48. Available at: http://journals.sagepub.com/doi/ pdf $/ 10.4256 /$ mio. 2010.0017

KODERMAN, M. (2012): Selected characteristics of roots tourism in Slovenia. Tourism: An International Interdisciplinary Journal, 60(4): 385-396.

KODERMAN, M., MIHELIČ PULSIPHER, L. (2012): Social and spatial aspects of roots tourism in Slovenia: the case of the Slovene-American diaspora. Dve Domovini - Two Homelands, (35): 163-175.

KONEČNIK, M. (2005): Uravnotežen pogled na znamko turistične destinacije. Turizam, 9(79): 4-5.

KRUJA, D., GJYREZI, A. (2011): The Special Interest Tourism Development and the Small Regions. Turizam, 15(2): 77-89.

KRŽIŠNIK-BUKIĆ, V. (2008): Narodnomanjšinsko vprašanje $\mathrm{v}$ Sloveniji po razpadu Jugoslavije: o družbeni upravičenosti vprašanja statusa narodnih manjšin Albancem, Bošnjakom, Črnogorcem, Hrvatom, Makedoncem in Srbom v republiki Sloveniji s predlogi za urejanje njihovega narodnomanjšinskega položaja. Razprave in gradivo, 56/57: 120-156.

KRŽIŠNIK-BUKIĆ， V., JOSIPOVIČ, D., RIZMAN， R., ŽITNIK SERAFIN, J. (2014): Zgodovinski, politološki, pravni in kulturološki okvir za definicijo narodne manjšine v Republiki Sloveniji. Ljubljana, Inštitut za narodnostna vprašanja.

KURTOVIĆ, L. (2011): Yugonostalgia on Wheels: Commemorating Marshal Tito across Post-Yugoslav Borders. Newsletter of the Institute of Slavic, East European, and Eurasian Studies, 28(1): 2-23.

KUZMANIĆ, M. (2008): Collective Memory and Social Identity: A social psychological exploration of the memories of the disintegration of former Yugoslavia. Psihološka Obzorja / Horizons of Psychology, 17(2): 5-26.
LEONG, A. M. W., YEH, S.-S., HSIAO, Y.-C., HUAN, T.C. T. C. (2015): Nostalgia as travel motivation and its impact on tourists' loyalty. Journal of Business Research, 68(1): 81-86.

LINDSTROM, N. (2005): Yugonostalgia: restorative and reflective nostalgia in former Yugoslavia. East Central Europe, 32(1-2): 227-237.

LOWENTHAL, D. (1999): The Past is a Foreign Country. Cambridge, Cambridge University Press.

MANSFELD, Y. KORMAN, T. (2015): Between war and peace: conflict heritage tourism along three Israeli border areas. Tourism Geographies, 17(3): 437-460.

MARCHEGIANI, C., PHAU, I. (2011): The value of historical nostalgia for marketing management. Marketing Intelligence \& Planning, 29(2): 108-122.

MCKERCHER, B. (2016): Towards a taxonomy of tourism products. Tourism Management, 54(June): 196-208.

MENDELSON, S. E., GERBER, T. P. (2005): Soviet Nostalgia: An Impediment to Russian Democratization. The Washington Quarterly, 29(1): 83-96.

MERCHANT, A., ROSE, G. M. (2013): Effects of advertisingevoked vicarious nostalgia on brand heritage. Journal of Business Research, 66(12): 2619-2625.

MUEHLING, D. D. (2013): The relative influence of advertising-evoked personal and historical nostalgic thoughts on consumers' brand attitudes. Journal of Marketing Communications, 19(2): 98-113.

NOVAK, F. (1968): Po Jugoslaviji. Quer durch Jugoslawien. Per la Jugoslavia. Across Jugoslavia. A travers la Yougoslavie. Kryssning Yugoslavien. Lovrenc na Pohorju, TD Turistbiro Pohorje.

OECD (2008). The Impact of Culture on Tourism. Paris: Organisation for Economic Co-operation and Development. [cit. 17.12.2016]. OECD. Availableat: http:// www.oecd-ilibrary.org/content/book/9789264040731-en

OPASCHOWSKI, H.W. (2001): Das gekaufte Paradies: Tourismus im 21. Jahrhundert. Hamburg: Germa-Press.

OSBALDISTON, N. (2012): Seeking Authenticity in Place, Culture, and the Self: The Great Urban Escape. New York, Palgrave Macmillan US.

OUSHAKINE, S. A. (2007): 'We're Nostalgic but We're Not Crazy': Retrofitting the past in Russia. The Russian Review, 66(3): 451-482.

PALMBERGER, M. (2008): Nostalgia matters: Nostalgia for Yugoslavia as potential vision for a better future. Sociologija: časopis za sociologiju, socijalnu psihologiju i socijalnu antropologiju, 50(4): 355-370.

PAUKER, I. (2006): Reconciliation and Popular Culture: A Promising Development In Former Yugoslavia? Localglobal: identity, security, community, 2: 72-81.

PETROVIĆ, T. (2013): Museums and Workers: Negotiating industrial heritage in the former Yugoslavia. Narodna Umjetnost: hrvatski časopis za etnologiju I folkloristiku, 50(1): 96-119.

PICKERING, M., KEIGHTLEY, E. (2006): The Modalities of Nostalgia. Current Sociology, 54(6): 919-941.

PRIOPĆENJE/FIRST RELEASE (2017). Croatian Bureau for statistics [cit. 15.11.2017]. Available at: https://www. dzs.hr/Hrv_Eng/publication/2016/04-03-02_01_2016.htm 
RABOTIĆ, B. (2014). Special-purpose travel in ancient times: 'Tourism' before tourism? Turističko Poslovanje, 14: 5-17.

RANČIĆ, M., BLEŠIĆ, I., ĐORĐEVIĆ J., BOLE, D. (2016): The Motives for Service Users Visiting the Wellness Centers in Slovenia. Acta geographica SlovenicaGeografski zbornik, 56(2): 193-208.

REKŚĆ, M. (2015): Nostalgia for Communism in the Collective Imagination. Procedia - Social and Behavioral Sciences, 183(2015): 105-114.

ROBINSON, M., NOVELLI, M. (2005): Niche tourism: an introduction. [cit. 17.12.2016]. In: Niche Tourism. Contemporary issues, trends and cases (pp. 1-11). Oxford, Butterworth-Heinemann. Available at: http://www.sciencedirect.com/science/article/pii/ B978075066133150007X

RYAN, C., SHUO, Y. (SAM) S., HUAN, T.-C. (2010): Theme parks and a structural equation model of determinants of visitor satisfaction - Janfusan Fancyworld, Taiwan. Journal of Vacation Marketing, 16 (3): 185-199.

SAARTS, T. (2016): The ethnic-colonial communist legacy and the formation of the Estonian and Latvian party systems. Trames - Journal of the Humanities and Social Sciences, 20(2): 115-143.

SAOPŠTENJA (PRESS) (2017，2015，2010). Agency for statistics of Bosnia and Herzegovina. [cit. 20.12.2016]. Available at: http://www.bhas.ba/ index.php?option $=$ com_saopstenje\&cbgodina_ saopstenja $=2017 \&$ pregled $=1 \&$ lang $=$ ba\&Itemid $=$

SIMMONS, C. (2009): Miljenko Jergović and (Yugo)nostalgia. Russian Literature, 66(4): 457-469.

SMEEKES, A. (2015): National nostalgia: A group-based emotion that benefits the in-group but hampers intergroup relations. International Journal of Intercultural Relations, 49(November 2015): 54-67.

SNIJDERS, A. B. T. (1992): Estimation on the basis of snowball samples: how to weight? Bulletin de méthodologie sociologique, 36(September 1992): 59-70.

STAROBINSKI, J. (2009): Poimanje nostalgije. Autsajderski fragmenti: časopis za kulturu, umjetnost i znanost, 2009(1-2): 57-72

STATISTICAL YEARBOOK 2016 (2016). Podgorica, Statistical Office of Montenegro - MONSTAT.

STATISTICAL YEARBOOK 2017 (2017). Podgorica, Statistical Office of Montenegro - MONSTAT.

STATISTICAL YEARBOOK OF THE REPUBLIC OF MACEDONIA, 2015 (2015). Skopje, State statistical office of the Republic of Macedonia.

STATISTICAL YEARBOOK OF THE REPUBLIC OF MACEDONIA, 2017 (2017). Skopje, State statistical office of the Republic of Macedonia.

STATISTICAL YEARBOOK OF THE REPUBLIC OF CROATIA, 2016 (2016). Zagreb, Croatian Bureau of Statistics.

STATISTICAL YEARBOOK OF THE REPUBLIC OF SERBIA, 2017 (2017). Statistical Office of the Republic of Serbia. [cit. 15.11.2017]. Available at: http://webrzs.stat.gov.rs/WebSite/repository/
documents/00/02/64/51/00-Statisticki_godisnjak_ Republike_Srbije,_2017.pdf

STEWART, S. (1993): On Longing: Narratives of the Miniature, the Gigantic, the Souvenir, the Collection. Durham, N. C., Duke University Press.

STEWART, W. P. (1998): Leisure as multiphase experiences. [cit. 17.12.2016]. Journal of Leisure Research, 30(4). Available at: https://experts.illinois.edu/en/ publications/leisure-as-multiphase-experienceschallenging-traditions

SPILLER, M. W, GILE， K. J., HANDCOCK, M. S., MAR, C. M., WEJNERT, C. (2018): Evaluating Variance Estimators for Respondent-Driven Sampling. Journal of survey statistics and methodology, 6(1): 23-45. Available at: http://dx.doi.org/10.1093/jssam/smx018 Retrieved from https://escholarship.org/uc/item/1j68h3tv

ŠEGOTA, T., JANČIČ, Z. (2012): Percepcija turistične ponudbe Hrvaške $\mathrm{v}$ očeh slovenskih obiskovalcev. Akademija MM, 11(20): 61-71.

ŠEGOTA, T., JANČIČ, Z. (2013): Are You Feeling Nostalgic, Neighbour? Academica Turistica. Tourism \& Innovation Journal, 6(2): 3-15.

ŠRAM, Z. (2001): Antizapadna orijentacija kao komponenta šire ideologijske matrice: slučaj Vojvodine. Politička misao, 38(2): 91-110.

ŠTETIĆ, S., ŠIMIČEVIĆ, D., ĆURČIĆ, N. (2013): Posebni oblici turizma. Beograd, Forma B.

ŠULIGOJ, M., ŠTRUKELJ, T. (2017): Socially responsible enterprises for sustainable future: greening practices from Slovenia. In: Renko, S., Peštek, A., Almir [eds.], Green economy in the Western Balkans: towards a sustainable future (pp. 241-284). London, Emerald Group Publishing.

TANNOCK, S. (1995): Nostalgia critique. Cultural Studies, 9(3): 453-464.

TCHOUKARINE, I. (2010): The Yugoslav Road to International Tourism. Opening, Decentralization, and Propaganda in the Early 1950s. In: Yugoslavia's Sunny Side. A History of Tourism in Socialism (1950s-1980s). Budapest/New York, Central European University Press.

TCHOUKARINE, I. (2015): Yugoslavia's Open-Door Policy and Global Tourism in the 1950s and 1960s. East European Politics \& Societies, 29(1): 168-188.

TODOROVA, M., GILLE, Z. (2012). Post-communist Nostalgia. New York, Berghahn Books.

TRAUER, B. (2006): Conceptualizing special interest tourism-frameworks for analysis. Tourism Management, 27(2): 183-200.

TUNG, V. W. S., RITCHIE, J. R. B. (2011): Exploring the essence of memorable tourism experiences. Annals of Tourism Research, 38(4): 1367-1386.

UGREŠIĆ, D. (1998): The Culture of Lies: Antipolitical Essays. University Park, PA, Pennsylvania State University Press.

UMPHLETT, W. L. (2006): From Television to the Internet: Postmodern Visions of American Media Culture in the Twentieth Century. Madison, Fairleigh Dickinson University Press. 
VELIKONJA, M. (2008): Titostalgija - študija nostalgije po Josipu Brozu. [cit. 19.11.2016]. Ljubljana, Mirovni inštitut. Available at: http://mediawatch.mirovniinstitut.si/edicija/seznam/20/mediawatch20.pdf

VELIKONJA, M., MAJSOVA, N. (2014): Lost planet Yugoslavia: ideological ambiguity of the ex-Yugoslavia related tourism. In: Hansen-Kokoru. R. [ed.]: Facing the present: transition in post-Yugoslavia. The artists' view (pp. 137-153). Hamburg, Kovač.

VOLČIČ, Z. (2007): Yugo-Nostalgia: Cultural Memory and Media in the Former Yugoslavia. Critical Studies in Media Communication, 24(1): 21-38.
WILDSCHUT, T., BRUDER, M., ROBERTSON, S., VAN TILBURG, W. A. P., SEDIKIDES, C. (2014): Collective nostalgia: A group-level emotion that confers unique benefits on the group. Journal of Personality and Social Psychology, 107(5): 844-863.

WONG, K. K. F., CHEUNG, P. W. Y. (1999): Strategic theming in theme park marketing. Journal of Vacation Marketing, 5(4): 319-332.

YOON, Y., UYSAL, M. (2005): An examination of the effects of motivation and satisfaction on destination loyalty: a structural model. Tourism Management, 26(1): 45-56.

\section{Please cite this article as:}

ŠULIGOJ, M. (2018): Characterising the flows of Slovenian tourists within the former Yugoslavia with respect to post-communist 'nostalgic context'. Moravian Geographical Reports, 26(1): 14-26. Doi: 10.2478/mgr-2018-0002. 